\title{
New Aspects of High-Mountain Palaeobiogeography: A Synthesis of Data from Forefields of Receding Glaciers and Ice Patches in the Tärna and Kebnekaise Mountains, Swedish Lapland
}

\author{
Leif Kullman ${ }^{1}$ and Lisa Öberg ${ }^{2}$
}

\author{
(Received 25 February 2014; accepted in revised form 7 August 2014)
}

\begin{abstract}
Recent recession of high-mountain glacier ice and perennial snow and ice patches has exposed megafossil and macrofossil tree remnants and peat, offering a new source of Holocene high alpine vegetation history in the Scandes. Radiocarbon dates of 90 tree megafossils from Swedish Lapland, 29 of which had not previously been published, range from 11980 to 1950 cal yr BP. During the interval $9500-8500$ cal yr BP, mountain birch (Betula pubescens ssp. czerepanovii) and Scots pine (Pinus sylvestris) grew 600-700 m higher upslope than they do today, which is a new and remarkable discovery. Subsequently, tree density gradually declined at higher elevations, and as the tree line moved downslope, the ratio of Betula to Pinus increased. Tree growth ceased around $4500 \mathrm{cal} \mathrm{yr} \mathrm{BP,} \mathrm{presumably} \mathrm{in} \mathrm{response} \mathrm{to} \mathrm{the} \mathrm{return} \mathrm{of} \mathrm{perennial} \mathrm{ice} \mathrm{and} \mathrm{snow.}$ A short episode of resumed tree growth of Betula indicates conditions warmer than present around 2000 years ago. Between c. 8500 and $7300 \mathrm{cal}$ yr BP, Picea abies, Larix sibirica, Populus tremula, Sorbus aucuparia and Alnus incana were subordinate species on a forest floor dominated by plant species characteristic of prealpine or subalpine woodlands. Growth of trees as much as $700 \mathrm{~m}$ higher upslope than today around $9500 \mathrm{cal} \mathrm{yr} \mathrm{BP}$ implies that summer temperatures at that time may have been $3.0^{\circ} \mathrm{C}$ warmer than today's temperatures (corrected for land uplift). This inferred temperature difference between the early Holocene and the present concurs with changes in the Earth's orbital parameters.
\end{abstract}

Key words: glaciers; tree growth; megafossils; macrofossils; Holocene; radiocarbon dating; climate change; Swedish Scandes

RÉSUMÉ. Le recul récent de la glace de glacier, de la neige pérenne et des bancs de glace en haute montagne a permis de découvrir des mégafossiles et des macrofossiles de restes d'arbres et de tourbe, ce qui offre une nouvelle source d'histoire de la végétation alpine des Scandes en haute altitude pendant l'Holocène. La datation au carbone 14 de 90 mégafossiles d'arbres en provenance de la Laponie suédoise, dont 29 n'avaient jamais fait l'objet d'une publication, donne des résultats variant de 11980 à 1950 années cal. BP. Au cours de l'intervalle allant de 9500 à 8500 années cal. BP, le bouleau de montagne (Betula pubescens ssp. czerepanovii) et le pin sylvestre (Pinus sylvestris) poussaient à une hauteur de 600 à $700 \mathrm{~m}$ plus élevée qu'aujourd'hui, ce qui représente une découverte à la fois nouvelle et remarquable. Subséquemment, la densité des arbres a diminué graduellement en haute altitude, et au fur et à mesure que la limite forestière s'est mise à descendre, le rapport entre Betula et Pinus s'est accru. La croissance des arbres a cessé vers 4500 années cal. BP, probablement en raison du retour de la glace et de la neige pérennes. Un bref épisode de reprise de la croissance des arbres de Betula indique la présence de conditions plus chaudes qu'à présent il y a environ 2000 ans. Entre 8500 et 7300 années cal. BP environ, Picea abies, Larix sibirica, Populus tremula, Sorbus aucuparia et Alnus incana étaient des espèces subordonnées sur une couverture morte dominée par des espèces végétales caractéristiques de terrains boisés préalpins ou subalpins. La croissance des arbres à une hauteur de $700 \mathrm{~m}$ plus élevée qu'aujourd'hui il y a environ 9500 années cal. BP implique qu'à cette époque, les températures estivales pouvaient être plus chaudes dans une mesure de $3,0{ }^{\circ} \mathrm{C}$ que les températures actuelles (donnée redressée en fonction du soulèvement de la terre). Cette différence inférée de température entre l'Holocène précoce et le présent converge avec les changements caractérisant les paramètres orbitaux de la Terre.

Mots clés : glaciers; croissance des arbres; mégafossiles; macrofossiles; Holocène; datation par le carbone 14; changement climatique; Scandes suédoises

Traduit pour la revue Arctic par Nicole Giguère.

\footnotetext{
${ }^{1}$ Corresponding author: Department of Ecology and Environmental Science, Umeå University, SE 90187 Umeå, Sweden; leif.kullman@emg.umu.se

${ }^{2}$ Department of Applied Science and Design, Mid Sweden University, SE 85170 Sundsvall, Sweden

(C) The Arctic Institute of North America
} 


\section{INTRODUCTION}

Megafossil tree remains preserved in low alpine peats and lake sediments have for some decades been successfully used for paleo tree line reconstruction (Karlén, 1976; Aas and Faarlund, 1988; Dahl and Nesje, 1996; Kullman, 1999, 2008, 2013; Paus, 2010). However, the virtual lack of these archives at very high elevations in the alpine zone has precluded accurate reconstruction of the highest postglacial elevation of tree growth, which hampers detailed understanding of past vegetation and climate evolution.

In many parts of the world, recent glacier recession has opened an entirely new window on the palaeoecology, vegetation history, and archaeology of sites at high elevations (Dyurgerov and Meier, 2000; Farnell et al., 2004; Dove et al., 2005; Nesje, 2009; Menounos et al., 2009; Nesje et al., 2011; Andrews and MacKay, 2012; Callanan, 2012). In forefields of mountain glaciers and perennial snow and ice patches, in most cases quite close to the tree line, exposure of megafossil tree remnants of different species spanning major parts of the Holocene is quite common (e.g., Nicolussi and Patzelt, 2000; Hormes et al., 2001; Schlüchter and Jörin, 2004; Koch et al., 2007; Benedict et al., 2008; Joerin et al., 2008; Wiles et al., 2008; Scapozza et al., 2010; Koehler and Smith, 2011; Nicolussi and Schlüchter, 2012). In the Swedish Scandes, reconnaissance surveys of these newly emerging habitats have highlighted a surprising plethora of debris wood currently being released from beneath receding perennial ice and snow bodies at unprecedented elevations high above the tree line (Kullman, 2004a; Öberg and Kullman, 2011a; Kullman and Öberg, 2012).

Here we report and analyze the results of an intensified search for recently exposed debris wood and peat from forefields of glaciers and icefields and snow patches in different parts of Swedish Lapland and at very high elevations above the tree line, presenting a comprehensive synthesis of new and previously published data (Öberg and Kullman, 2011a; Kullman and Öberg, 2012). The present extended sampling effort adds to the understanding of the upper limit, general structure, species composition of tree growth, and palaeoclimate during earlier parts of the Holocene.

\section{STUDY AREA}

The study area includes two main areas in the province of Lapland in the northern part of the Swedish Scandes: Tärna in the south and Abisko-Kebnekaise in the north (Fig. 1). Geographical names are given in Swedish according to official topographic maps.

The highest peaks range between 1400 and $2100 \mathrm{~m}$ above sea level (a.s.1.), while the valley floors are at 500 to $700 \mathrm{~m}$ a.s.l. The bedrock is of Cambro-Silurian origin (amphibolite, greenschist, and calcareous phyllite) and the Quaternary deposits consist of peat, till, glacifluvial, and loessic accumulations. The climate is weakly suboceanic. More detailed site descriptions and accounts of the physiography,

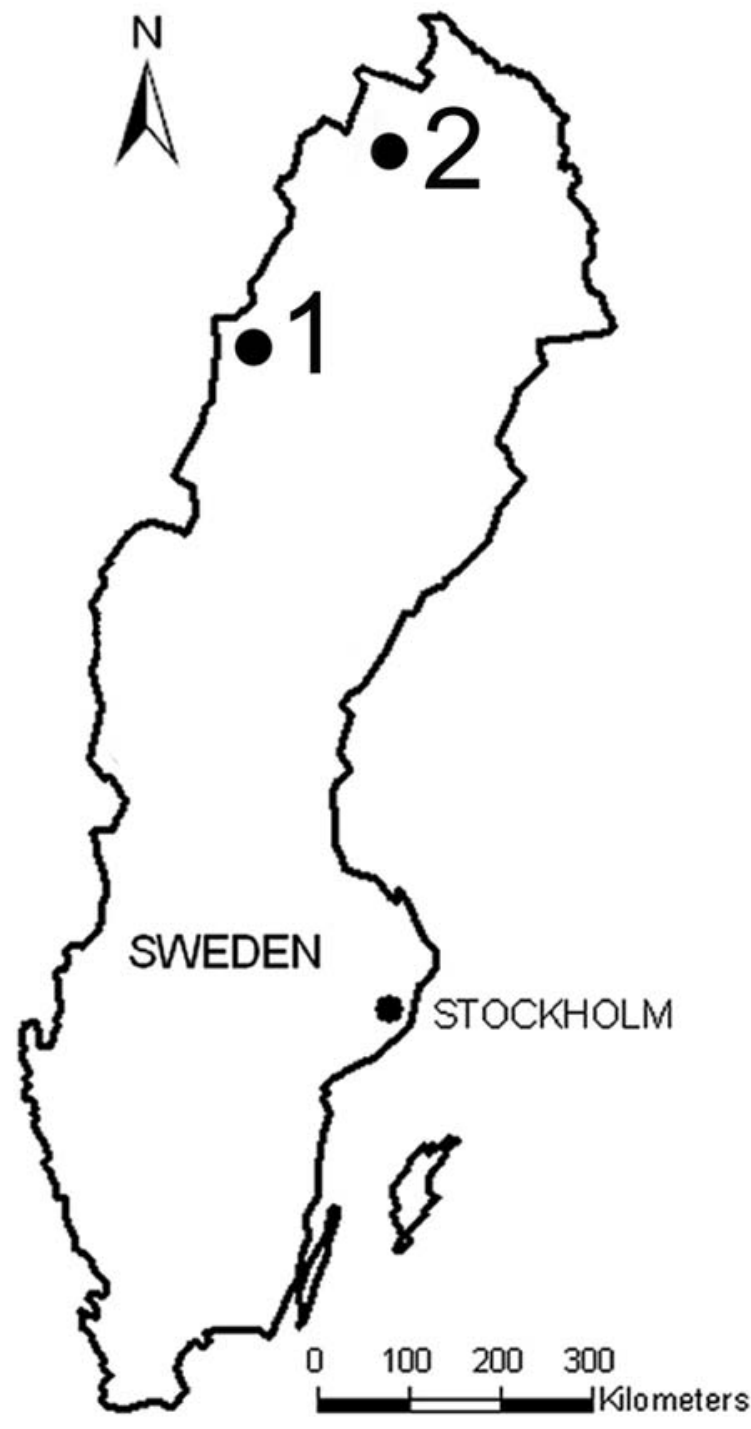

FIG. 1. Location of the study areas in Swedish Lapland: 1) Tärna, and 2) Abisko/Kebnekaise.

local climate, and Holocene glacier histories are provided elsewhere (Gavelin, 1910; Svenonius, 1910; Ahlmann and Lindblad, 1940; Schytt, 1959; Karlén, 1973; Holmlund et al., 1996; Lindgren and Strömgren, 2001).

The general character of the forefields fringing the glaciers we focus on in this study is displayed in Figure 2. Representative views of the investigated snow and ice patch sites are presented by Öberg and Kullman (2011a) and Kullman and Öberg (2012).

The valleys and mountainsides are clad with an upper forest rim of mountain birch (Betula pubescens ssp. czerepanovii), with scattered specimens of Scots pine (Pinus sylvestris) and Norway spruce (Picea abies). The present-day (2010 - 13) local tree lines, set by Betula, Picea, and Pinus trees more than $2 \mathrm{~m}$ tall (Fig. 3), are used as modern references when calculating the magnitude of past changes in tree-line elevation throughout the Holocene (Appendix 1). 

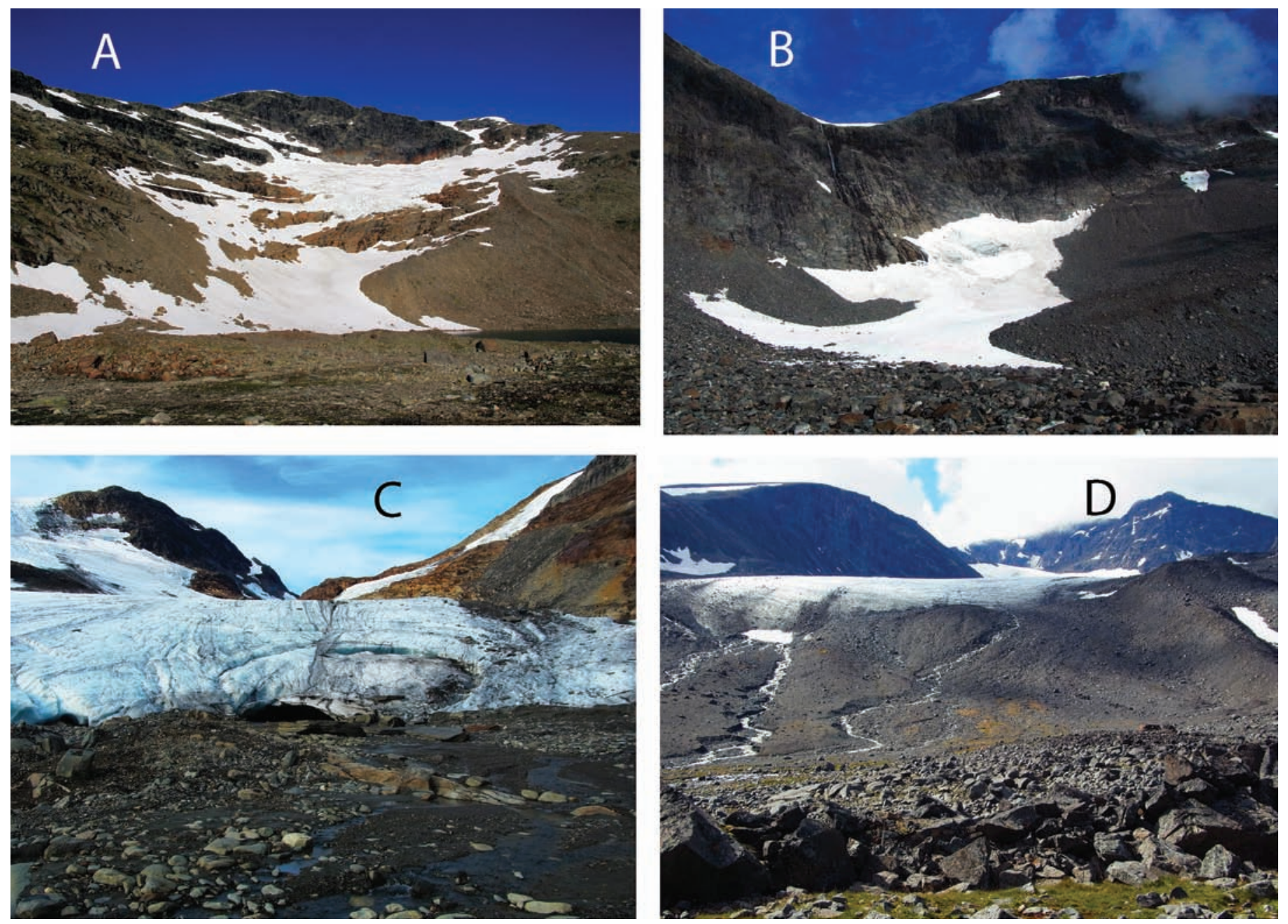

FIG. 2. Lower margins and forefields of the glaciers concerned in this study. A) Tärnaglaciären, B) Kittelglaciären, C) Kårsajökeln, and D) Storglaciären.

\section{METHODS}

The surfaces of glacier forefields were systematically searched for megafossil tree and peat remains during the late summer and early autumn of 2012 and 2013. Recovered specimens were instantly wrapped in aluminum foil and stored frozen until delivery to the dating laboratory. Only complete and spatially well separated wood pieces were dated. Thus, the risk of dating wood belonging to different specimens is negligible. This kind of sampling cannot guarantee achievement of a perfectly true representation of tree dates for each time; however, a large sample size may substantially reduce the uncertainty. This improved accuracy is most relevant for the balance between pine and birch, since birch decomposes more rapidly than pine.

Radiocarbon dating was performed by Beta Analytic Inc., Miami (USA). Radiocarbon ages are calibrated to calendar years before present (cal yr BP), with "present" = AD 1950. Dating was carried out after pretreatment with standard laboratory procedures. Calibration was conducted by use of the INTCAL09 database (Reimer et al., 2009). In cases when simplicity is needed (running text and Fig. 6), the calibrated ages are quoted as the values of points where radiocarbon ages intercept the calibration curve. We recognize that these estimates are not ideal. For the present purpose, however, they are considered to be adequate, particularly since they provide data compatible with data from previous studies (Öberg and Kullman, 2011a; Kullman and Öberg, 2012). The discussion is based on the radiocarbon time scale.

Outwashed peat cakes recovered on the forefields were dated on the basis of $2 \mathrm{~cm}$ slices of bulk peat samples. Some of these were coarsely analyzed for the presence of macroscopic tree remains, which were dated by accelerator mass spectrometry (AMS). In some cases, macroremains of Picea abies and understory species were dated indirectly by the radiocarbon age of the thin peat slice in which they were imbedded. In other cases, approximate ages of representatives of the last-mentioned group were estimated from dated wood samples contained in the same peat slices.

Great effort was devoted to searching alpine tundra (lakes, soils, and mires) slightly below and above the forefields here concerned for the presence of megafossils.

In most cases, the recovered megafossils had remaining bark fragments or cone and leaf characteristics that made species identification unambiguous. Some ambiguous 


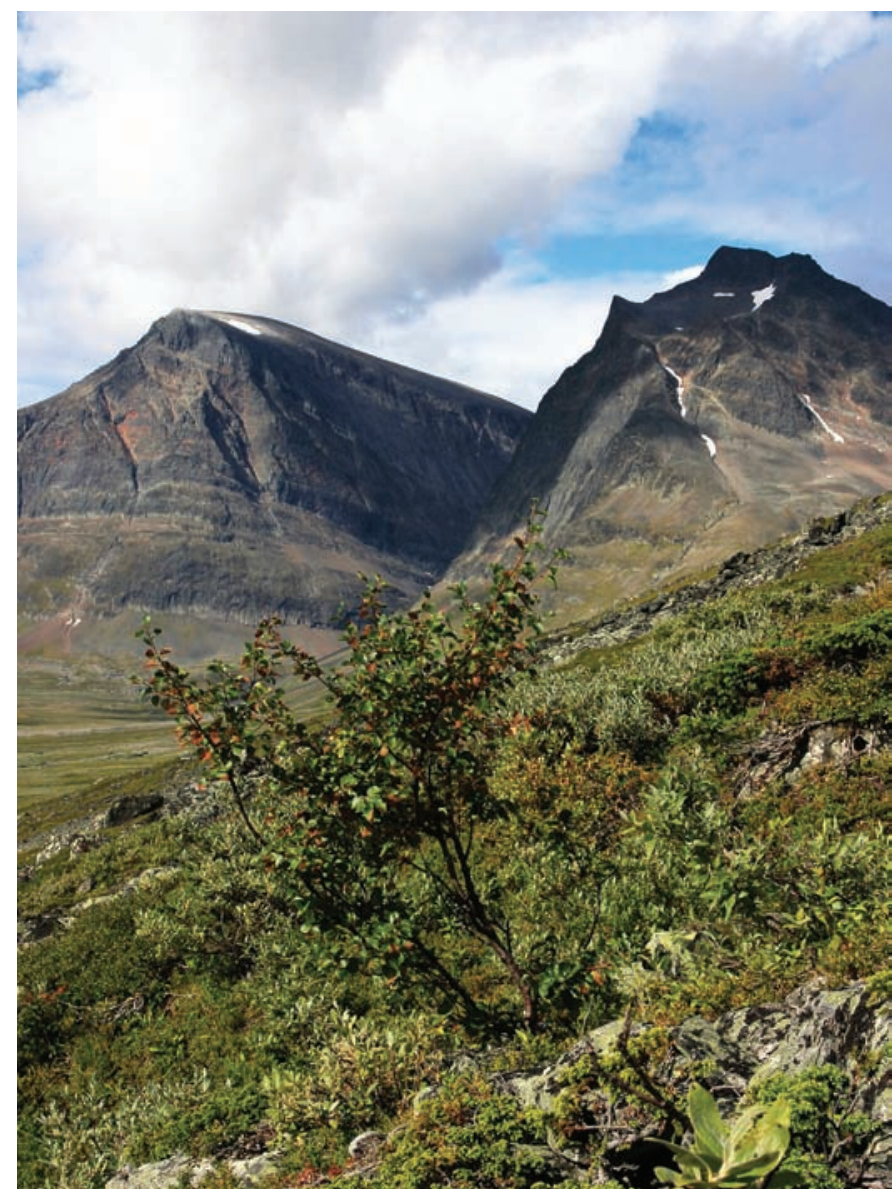

FIG. 3. The current tree line of mountain birch (Betula pubescens ssp. czerepanovii) on the south-facing slope of Mt. Kebnetjåkka, $3.5 \mathrm{~km}$ southeast of Kittelglaciären, is marked by this individual tree, growing at $910 \mathrm{~m}$ a.s.1. Over the past century, the tree line has shifted $170 \mathrm{~m}$ upslope. Photo: 2013 08-12.

specimens were identified by wood anatomy analysis (Erik Danielsson/Vedlab Inc.). Altitudes (m a.s.1.) and geographical coordinates of all retrieved tree remains were obtained by a GPS navigator (Garmin 60CS) that was repeatedly calibrated against distinct points on the topographical map. Reported altitudes are rounded off to the nearest $5 \mathrm{~m}$. The nomenclature of vascular plants follows Mossberg and Stenberg (2003).

\section{RESULTS}

\section{General Character of Samples and Sites}

The representative overview of the general character of tree remains, peat samples, and their discovery sites provided by Öberg and Kullman (2011a) and Kullman and Öberg (2012) is complemented here by a few examples (Fig. 4).

Characteristically, detrital wood and peat cakes occurred in close association with main glacier outwash streams, originating from beneath glacier ice within a few hundred meters of the ice fronts. Obviously, original growing sites are still hidden by permanent ice upstream and at higher elevations. Thus, the sampling sites represent minimum elevations of the original growing sites. Some of the snow and ice patches occur in relatively flat terrain, indicating that recovered megafossils are nearly in situ.

Most of the sampled wood remains were short sections of logs, $0.2-0.5 \mathrm{~m}$ in length and $5-15 \mathrm{~cm}$ in diameter. As a rule, they appeared to have been recently broken, often displaying soft, rapidly disintegrating, and strongly compressed wood indicative of subglacial burial and transport. Usually, only fragments of the bark remained. In some cases, macroremains of various tree species were found as cones, bark, needles and leaf fragments embedded in peat cakes with a size of $10-20 \mathrm{~cm}$ (Fig. 5). Their rounded, somewhat compressed, and compact forms suggest that they had been dislocated by streaming water from their original growth positions, which were still covered by ice. It is reasonable to suppose that many pieces of tree remains were preserved in peat for some millennia prior to the glacier inception, which further contributed to their conservation.

In addition to wood fragments, peat cakes are regularly recovered along the outwash streams. The small fraction of these that have been dated range in age from 3900 to 8400 cal yr BP. As a rule, the peat contains plant macrofossils easily identifiable as common understory forest species and tree species such as Picea abies $(8450,8380$, and 8180 cal yr BP), Larix sibirica (7320 cal yr BP), Sorbus aucuparia (8640 cal yr BP), Alnus incana (8000 cal yr BP), and Populus tremula (8590 cal yr BP) (Kullman and Öberg, 2012; Appendix 1).

\section{Chronology and Elevational Structure}

In total, 90 tree remains, distributed among the seven sampling sites, were radiocarbon-dated; ages ranged from 1950 to 11980 cal yr BP (Appendix 1). Of these 90, 29 are here reported for the first time. Betula is the dominant species (53), followed in order of abundance by Pinus sylvestris (30), Picea abies (4), Larix sibirica (1), Populus tremula (1), Alnus incana (1), and Sorbus aucuparia (1).

Figure 6 displays the calibrated radiocarbon ages of all recovered birch and pine megafossils relative to their present-day tree-line elevations in the study area. Except for a pine remnant dated to 11760 cal yr BP (i.e., right at the Late Glacial/Holocene transition), no tree records originate from the first 2000 years of the Holocene. Around $9500 \mathrm{cal}$ yr BP, a distinct surge of pine and birch dates emerges in the record at elevations 600 to $700 \mathrm{~m}$ higher than the present-day tree lines of these species. Records from these high relative elevations remained for about 1000 years. Shortly after 8500 cal yr BP, an abrupt elevational dip of approximately $200 \mathrm{~m}$ occurred. Thereafter, a more linear descent of Pinus and Betula proceeded until about 4500 cal yr BP, after which the records of pine and birch are virtually absent. During this later interval, birch appears to have gained in dominance relative to pine. Notably, a single birch $\log$ is dated to 1950 cal yr BP (Appendix 1, Fig. 6). 

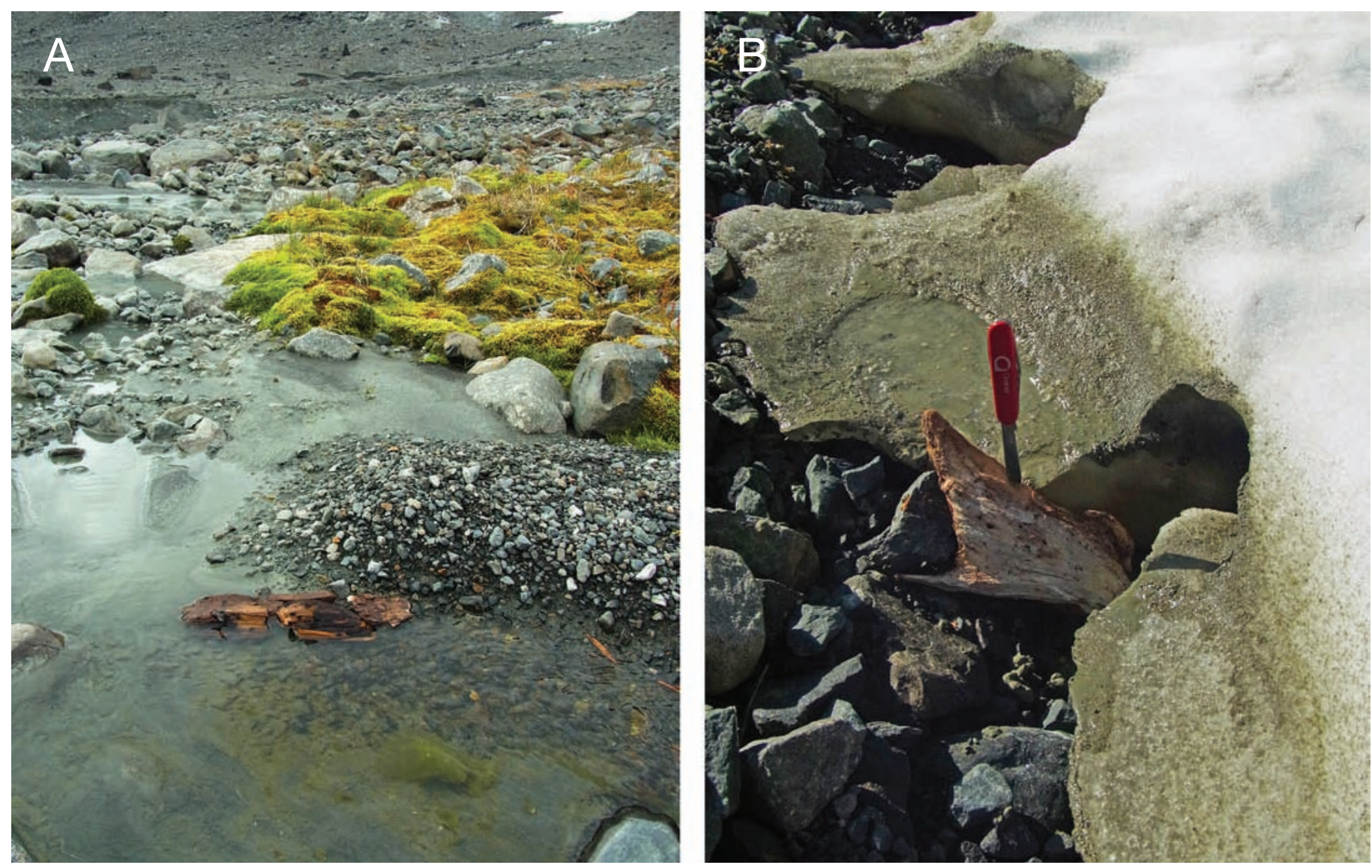

FIG. 4. Megafossil tree remains sampled at different sites. A) Storglaciären, Betula pubescens 8490 cal yr BP, B) Kittelglaciären, Pinus sylvestris 9010 cal yr BP.

\section{DISCUSSION AND INTERPRETATION}

\section{High-Elevation Tree Growth and Landscape History}

The virtual absence of megafossil tree records for the first 2000 years of the Holocene differs from the pattern of other high-mountain parts of the Scandes, where scattered trees grew during this period but exclusively at much lower elevations relative to the present-day tree line (Kullman, 2002, 2013; Öberg and Kullman, 2011b). Apart from sampling stochasticity, this feature may relate to the particular high-altitude habitats concerned here, where snow and ice may build up quite rapidly as a consequence of episodes with modest cooling (cf. Jansson et al., 1999), making tree growth virtually impossible. In fact, shortterm glacier advances are inferred from this period in the Norwegian Scandes (Nesje, 2009). Subsequently and until the mid-Holocene, a diverse tree flora characterized glacier and snow cirques without perennial ice and currently situated several hundred meters above modern tree lines. These results parallel the situation in the southern Swedish Scandes (Öberg and Kullman, 2011a), suggesting a more generic pattern, with a richer tree flora and wider amplitude of Holocene tree-line and landscape change, than is usually assumed when focusing on more traditional palaeoarchives, such as peat bogs, soils, and lakes (e.g., Berglund et al., 1996; Karlén and Kuylenstierna, 1996;
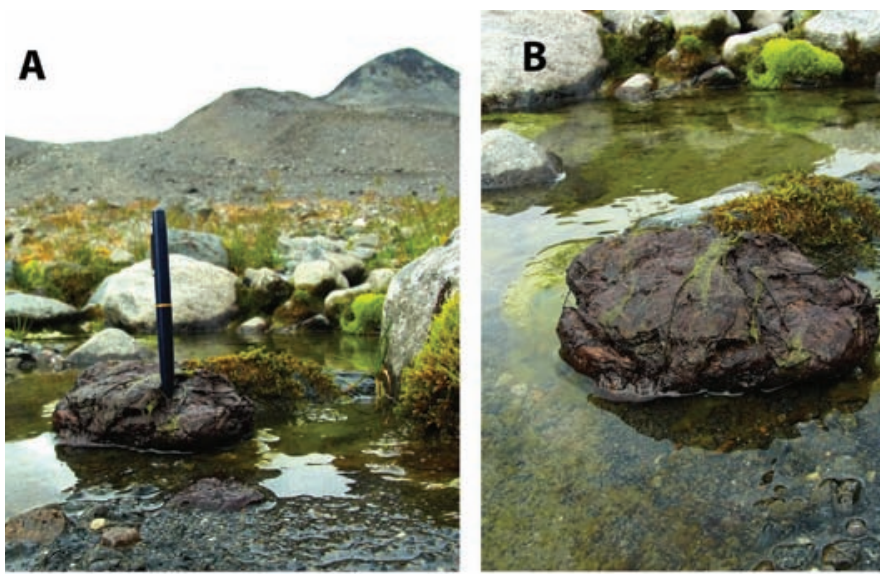

C
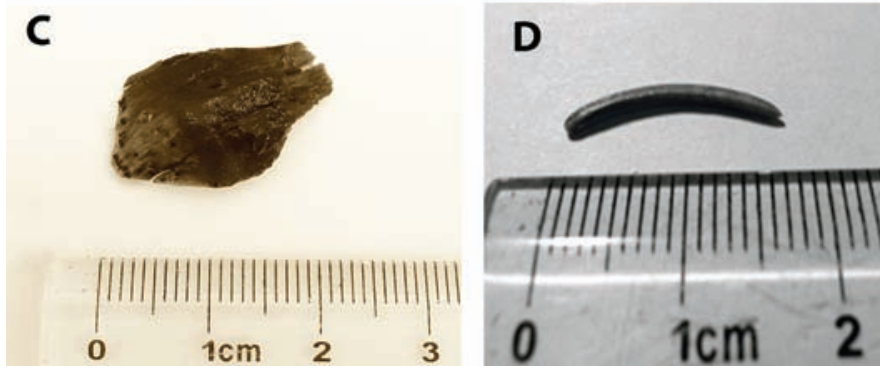

FIG. 5. A and B) Peat cake outwashed from Storglaciären, containing plant macrofossils, C) Cone shell of Picea abies 8380 cal yr BP, D) Picea abies needle 8380 cal yr BP. 


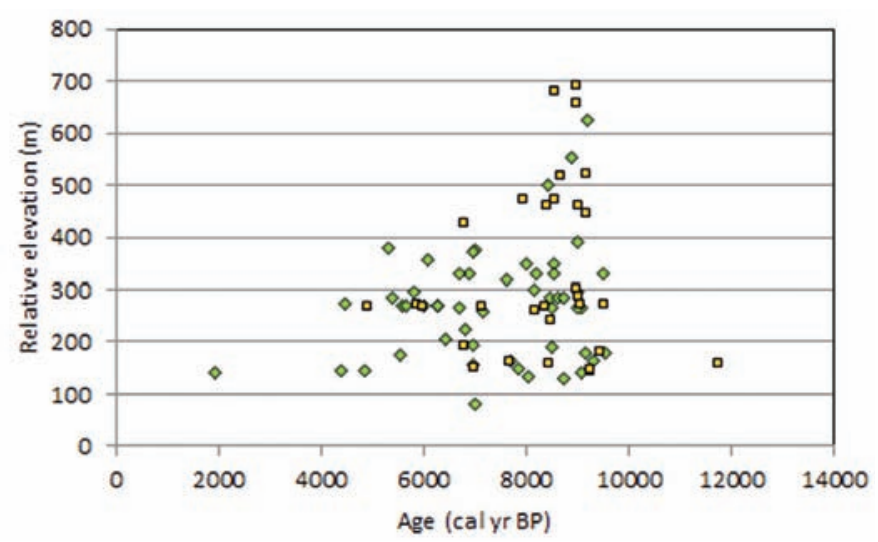

FIG. 6. Radiocarbon dates (intercept values) and corresponding elevations of all birch (green) and pine (yellow) remnants, relative to their present-day tree-line positions.

Barnekow, 1999; Seppä and Birks, 2001; Bergman et al., 2005; Mahaney and Kalm, 2012).

Tree growth $600-700 \mathrm{~m}$ above the modern tree lines in 9500-8500 cal yr BP, as evidenced here for a particular type of habitat, is several hundred meters higher than estimated for the same time interval in previous studies that focused on low alpine terrain (e.g., Berglund et al., 1996; Karlén and Kuylenstierna, 1996; Barnekow, 1999; Seppä et al., 2004). Within an elevational zone $200-300 \mathrm{~m}$ below the glacier cirques, no megafossil or macrofossil evidence for tree growth could be found either in our study area or in other parts of the Scandes (Kullman, 1995, 2013; Paus, 2010; Öberg and Kullman, 2011a). Thus, it appears that between 9500 and 8500 cal yr BP, present-day glacier and ice patch sites stood out as more or less isolated "wood islands" in a virtually treeless landscape matrix. Thereafter, these islands gradually contracted in size and began to occur at lower elevations. In parallel, birch seems to have gained in relative dominance, after a period when pine was more prominent than previously presumed (e.g., Barnekow, 1999; Seppä et al., 2004).

Isolated multi-species tree islands, restricted to these specific outlier habitats (glacier cirques) high above present-day tree lines, may seem counterintuitive today. They could be understood, however, primarily in light of their particular concave (parabolic) local topography and associated climate, as suggestively illustrated by Öberg and Kullman (2011a). During warmer periods with less ice and snow, sites of this character are likely to provide higher temperatures, better wind shelter, and more stable soil moisture than much of the surrounding and more exposed high mountain landscape (cf. Elven, 1978; Anderson et al., 2009; Scherrer and Körner, 2011). Some further support for the latter contention is provided by frequent observations that these habitats have been particularly targeted by upward expansion of "forest species" in connection with the current warm phase of the climate (Kullman, 2004b, 2010; Öberg and Kullman, 2011a). With their propensity for snow accumulation, these sites offer ideal preconditions for accumulation of wind-driven seeds (Kullman, 1984, 2004b).
Today, tree growth of Betula reaches tree-line positions about 200 higher than that of Pinus in the study region. The present record provides no clear indication of whether such a situation also prevailed during the early Holocene within the habitats concerned here. It may appear that pine extended somewhat higher relative to its present-day position than did birch, i.e., the vertical separation between birch and pine may have been smaller than it is today. However, it should be kept in mind that the present record is somewhat fortuitous and incomplete, being composed of wood remains that have been dislocated downslope from their original growing sites. Thus, these samples (Fig. 6) at best provide only a subdued view of the tree species zonation pattern and the positional tree-line evolution throughout the Holocene.

A virtually new discovery emerging from this and analogous earlier studies (Öberg and Kullman, 2011a; Kullman and Öberg, 2012) is that during the early Holocene, high alpine forest islands composed predominantly of birch and pine were intermixed with scattered specimens of Picea abies, Larix sibirica, Populus tremula, Sorbus aucuparia, and Alnus incana. This relatively rich arboreal high mountain flora is paralleled at lower elevations in the mountain region with several warmth-demanding tree species that currently are not growing in the region (Kullman, 2008; Öberg and Kullman, 2011b).

The presence of Picea abies and Larix sibirica within the interval 8500-7300 cal yr BP contributes to a growing recognition and insight that these species were regular components of the high-mountain flora within the entire extent of the Scandes, from south to north, during the early Holocene and late Weichselian (Kullman, 2002, 2008; Paus, 2010, 2013; Öberg and Kullman, 2011b; Paus et al., 2011; Carcaillet et al., 2012). These features were previously entirely undetected by traditional pollen analysis (cf. Elven et al., 2013). Obviously, a much higher non-analogue biodiversity prevailed during the early Holocene than has ever been supposed for high-mountain regions.

Given the rich tree flora in isolated high alpine habitats during the early Holocene, when lower reaches of the mountain valleys were still ice-covered (e.g., Kullman, 1995; Barnekow, 1999), it is reasonable to assume that such populations have functioned as dispersal nodes for downslope afforestation of the high-mountain landscape (cf. Allen and Huntley, 1999; Kullman, 2002; Kullman and Kjällgren, 2006; Carcaillet et al., 2012). This aspect adds to the current discourse concerning the role of small outlier populations for understanding past, present, and future arboreal biogeography (e.g., Feurdean et al., 2013).

\section{Aspects on Glacier and Climate History}

The striking and rapid surge of warming-induced growth of Pinus and Betula at their highest Holocene levels during 9500-8500 cal yr BP appears to be a common pattern for the entire Scandes (Aas and Faarlund, 1988; Bjune et al., 2005; Eide et al., 2006; Paus, 2010). Apparently, this 
widespread phenomenon represents a release from the socalled Erdalen 2 Event (10100 to 9700 cal yr BP), which was characterized by distinct cooling and major glacier advance (Nesje et al., 1991; Dahl and Nesje, 1996).

The tight clustering of our dated tree remains suggests that at the end of this period of rapid tree growth, the glaciers and ice patches we are concerned with here did not exist, or were much smaller than they are today, in response to warmer-than-present summers. This situation prevailed throughout most (or all) of the period 9530-4480 cal yr BP, as inferred also in other studies in Scandinavia (e.g., Rosqvist and Østrem, 1989; Bakke et al., 2005; Nesje et al., 2008; Öberg and Kullman, 2011a). It is reasonable to conclude that this circumstance reflects a hemispheric climatic situation related to higher-than-present insolation levels, forced largely by the Earth's orbital variations (Ekholm, 1901; Berger and Loutre, 1991). Obviously, this mechanism has been the ultimate driver of a climate progressively more amenable to glacier expansion throughout the Holocene. Little support remains for repeated major glacier advances and retreats during this period (e.g., Karlén and Kuylenstierna, 1996), as concluded in several other studies (e.g., Berglund et al., 1996; Nesje, 2009).

The youngest peat date (3890 cal yr BP) constrains the continuous "tree period" and approximates the inception of perennial snow and glacier ice, which buried the last living trees and further sealed with ice those peat repositories that contained megafossils from earlier parts of the Holocene. This inference agrees with several studies indicating a distinct shift to cooler and more snow rich conditions (Neoglaciation) around that time (e.g., Karlén, 1976; Caseldine and Matthews, 1987; Snowball and Sandgren, 1996; Bergman et al., 2005; Paus, 2010; Kullman, 2013).

Notably, a single medium-sized birch log was recovered close to the lower, present-day front of the Kårsajökel and $140 \mathrm{~m}$ above the modern birch tree line (Fig. 4). Its date of $1950 \mathrm{cal} \mathrm{yr}$ BP indicates that, at that time, the glacier was more contracted upslope than at present and by inference, that this log may tentatively point to a period warmer than the present. In fact, this contention is supported by a reported finding near a glacier in SW Norway of a subfossil birch log, also located $140 \mathrm{~m}$ above the present tree line, and dating to about $2000 \mathrm{cal}$ yr BP (Nesje et al., 1991). Futhermore, an Icelandic glacier has released a birch log originating from virtually the same time (Ives, 1991). In line with these findings, several other climate proxies from northern Europe indicate warmer-than-present conditions in the first decades of the Roman Empire (e.g., Hormes et al., 2004; Ljungqvist, 2009; Humlum et al., 2011; Esper et al., 2012; Kullman, 2013; Luetscher et al., 2013). Moreover, the discovery of this birch log adds to the insight that present-day glacier recession and associated warming are not unique phenomena during the past 4500 years (cf. Kullman, 2013).

If we assume that the tree line and tree-line change relate primarily to summer temperature (e.g., Körner and Paulsen, 2004; Holtmeier and Broll, 2005), former tree-line positions may be used as proxy indicators of paleoclimate history (cf. Karlén 1976; Tinner and Kaltenrieder, 2005; Kirdyanov et al., 2012; Kullman, 2013), drawing on a conventional temperature lapse rate of $0.6^{\circ} \mathrm{C}$ per $100 \mathrm{~m}$ in elevation (Laaksonen, 1976). Given these assumptions, the Holocene tree-line peaks, at $9500 \mathrm{cal} \mathrm{yr} \mathrm{BP}$ and about $700 \mathrm{~m}$ higher than present, may imply summer temperatures $4.2^{\circ} \mathrm{C}$ warmer than the first decade of the present century. This is a minimum difference, since most megafossils are downwashed from elevations higher than their sampling sites. As a consequence, the temporal record of dated megafossil tree remains provides only a weak impression of long-term summer temperature variations.

To some extent, the emerging evidence of multi-species early Holocene tree growth at unprecedented high elevations relates to substantial glacio-isostatic uplift throughout the Holocene. Since about $9500 \mathrm{cal}$ yr BP, the land surface in western Lapland has been lifted by at least $200 \mathrm{~m}$ (e.g., Möller, 1987; Svensson, 1991; Påsse and Andersson, 2005). Thus, the total tree-line lowering attributable to general climate forcing should be reduced to $500 \mathrm{~m}$ (700 minus 200), which reduces the inferred change in summer temperature from $9500 \mathrm{cal} \mathrm{yr} \mathrm{BP}$ to the present to $3.0^{\circ} \mathrm{C}$. This lower estimate matches theoretical calculations based on insolation variations in response to the Earth's orbital changes (cf. Berger and Loutre, 1991; Esper et al., 2012) and compares well with multi-proxy reconstructions from adjacent parts of northern Lapland (Shemesh et al., 2001; Bigler et al., 2003).

Despite the reservations and uncertainties outlined above, there is little doubt that the Holocene thermal optimum for the Scandes occurred in the earliest part of the Holocene, which concurs with multi-proxy inferences from other parts of Europe and Greenland (e.g., Paus, 2013; Luoto et al., 2014). Other studies suggest a substantially later thermal optimum (e.g., Berglund et al., 1996; Seppä and Birks, 2001). However, these reconstructions are based on pollen analysis, an approach that is considered to provide less reliable temperature estimates (Paus, 2013; Elven et al., 2013).

The present study has provided a new and virtually unexpected view of the general structure and species composition of the high-mountain landscape in northern Sweden during the Holocene. The methodological approach depends entirely on rapid melting of perennial ice and snow bodies, which makes them sensitive to annual weather anomalies. Continued research and extensive field inventories urgently need to be implemented in order to gain even more information from these rich sources concerning the structure and species composition of the living mountain landscape in the past.

\section{ACKNOWLEDGEMENTS}

This study was funded by a grant (to Leif Kullman) from the Göran Gustafsson Foundation. We appreciate comments on the manuscript by Atle Nesje and two anonymous reviewers. 


\section{REFERENCES}

Aas, B., and Faarlund, T. 1988. Postglasiale skoggrenser i sørnorske fjelltrakter. ${ }^{14} \mathrm{C}$-datering av subfossile furu- og bjørkerester [Post-glacial forest limits in the central south Norwegian mountains. Radiocarbon datings of subfossil pine and birch specimens]. Norsk Geografisk Tidsskrift 42(1):25-61. http://dx.doi.org/10.1080/00291958808552183

Ahlmann, H., and Lindblad, T. 1940. Die Grössenveränderungen des Kårsajökels in Schwedisch-Lappland während der Jahre 1909-1939 [Changes in size of the Kårsajökels in Swedish Lappland during the years 1909-1939]. Geografiska Annaler 22:80-94. http://dx.doi.org/10.2307/519978

Allen, J.R.M., and Huntley, B. 1999. Estimating past floristic diversity in montane regions from macrofossil assemblages. Journal of Biogeography 26(1):55-73. http://dx.doi.org/10.1046/j.1365-2699.1999.00284.x

Anderson, P.M., Lozhkin, A.V., Solomatkina, T.B., and Brown, T.A. 2009. Paleoclimatic implications of glacial and postglacial refugia for Pinus pumila in western Beringia. Quaternary Research 73(2):269-276. http://dx.doi.org/10.1016/j.yqres.2009.09.008

Andrews, T.D., and MacKay, G. 2012. The archaeology and palaeoecology of alpine ice patches: A global perspective. Arctic 65(Suppl. 1):iii-vi. http://dx.doi.org/10.14430/arctic4181

Bakke, J., Dahl, S.O., Paasche, Ø., Løvlie, R., and Nesje, A. 2005. Glacier fluctuations, equilibrium-line altitudes and palaeoclimate in Lyngen, northern Norway, during the Lateglacial and Holocene. The Holocene 15(4):518 -540. http://dx.doi.org/10.1191/0959683605hl815rp

Barnekow, L. 1999. Holocene tree-line dynamics and inferred climatic changes in the Abisko area, northern Sweden, based on macrofossil and pollen records. The Holocene 9(3):253-265. http://dx.doi.org/10.1191/095968399676322637

Benedict, J.B., Benedict, R.J., Lee, C.M., and Staley, D.M. 2008. Spruce trees from a melting ice patch: Evidence for Holocene climatic change in the Colorado Rocky Mountains, USA. The Holocene 18(7):1067-1076. http://dx.doi.org/10.1177/0959683608095578

Berger, A., and Loutre, M.F. 1991. Insolation values for the climate of the last 10 million years. Quaternary Science Reviews 10(4):297-317. http://dx.doi.org/10.1016/0277-3791(91)90033-Q

Berglund, B.E., Barnekow, L., Hammarlund, D., Sandgren, P., and Snowball, I.F. 1996. Holocene forest dynamics and climate changes in the Abisko area, northern Sweden - the Sonesson model of vegetation history reconsidered and confirmed. Ecological Bulletins 45:15-30.

http://www.jstor.org/stable/20113180

Bergman, J., Hammarlund, D., Hannon, G., Barnekow, L., and Wohlfarth, B. 2005. Deglacial vegetation succession and Holocene tree-limit dynamics in the Scandes Mountains, westcentral Sweden: Stratigraphic data compared to megafossil evidence. Review of Palaeobotany and Palynology 134(34):129-151.

http://dx.doi.org/10.1016/j.revpalbo.2004.12.005
Bigler, C., Grahn, E., Laroque, I., Jeziorski, A., and Hall, R. 2003. Holocene environmental change at Lake Njulla (999 m a.s.1.), northern Sweden: A comparison with four small nearby lakes along an altitudinal gradient. Journal of Paleolimnology 29(1):13-29.

http://dx.doi.org/10.1023/A:1022850925937

Bjune, A.E., Bakke, J., Nesje, A., and Birks, H.J.B. 2005. Holocene mean July temperature and winter precipitation in western Norway inferred from palynological and glaciological lake sediment proxies. The Holocene 1(2):177-189. http://dx.doi.org/10.1191/0959683605h1798rp

Callanan, M. 2012. Central Norwegian snow patch archaeology: Patterns past and present. Arctic 65(Suppl. 1):178-188. http://dx.doi.org/10.14430/arctic4192

Carcaillet, C., Hörnberg, G., and Zackrisson, O. 2012. Woody vegetation, fuel and fire track the melting of the Scandinavian ice-sheet before 9500 cal yr BP. Quaternary Research 78(3):540-548.

http://dx.doi.org/10.1016/j.yqres.2012.08.001

Caseldine, C.J., and Matthews, J.A. 1987. Podzol development, vegetation change and glacier variations at Haugabreen, southern Norway. Boreas 16(3):215-230.

http://dx.doi.org/10.1111/j.1502-3885.1987.tb00089.x

Dahl, S.O., and Nesje, A. 1996. A new approach to calculating Holocene winter precipitation by combining glacier equilibrium-line altitudes and pine-tree limits: A case study from Hardangerjøkulen, central southern Norway. The Holocene 6(4):381-398. http://dx.doi.org/10.1177/095968369600600401

Dove, C.J., Hare, P.G., and Heacker, M. 2005. Identification of ancient feather fragments in melting alpine ice patches in southern Yukon. Arctic 58(1):38-43.

http://dx.doi.org/10.14430/arctic387

Dyurgerov, M.B., and Meier, M.F. 2000. Twentieth century climate change: Evidence from small glaciers. Proceedings of the National Academy of Sciences 97(4):1406-1411. http://dx.doi.org/10.1073/pnas.97.4.1406

Eide, W., Birks, H.H., Bigelow, N.H., Peglar, S.M., and Birks, H.J.B. 2006. Holocene tree migrations in the Setesdal valley, southern Norway, reconstructed from macrofossil and pollen evidence. Vegetation History and Archaeobotany 15(2):65 - 85. http://dx.doi.org/10.1007/s00334-005-0025-7

Ekholm, N. 1901. On the variations of the climate of the geological and historical past and their causes. Quarterly Journal of the Royal Meteorological Society 27(117):1-62. http://dx.doi.org/10.1002/qj.49702711702

Elven, R. 1978. Subglacial plant remains from Omnsbreen glacier area, south Norway. Boreas 7(2):83-89. http://dx.doi.org/10.1111/j.1502-3885.1978.tb00266.x

Elven, R., Fremstad, E., and Pedersen, O. 2013. Distribution maps of Norwegian vascular plants. Trondheim: Akademika Publishing.

Esper, J., Frank, D.C., Timonen, M., Zorita, E., Wilson, R.J.S., Luterbacher, J., Holzkämper, S., et al. 2012. Orbital forcing of tree-ring data. Nature Climate Change 2:862-866.

http://dx.doi.org/10.1038/nclimate1589 
Farnell, R., Hare, P.G., Blake, E., Bowyer, V., Schweger, C., Greer, S., and Gotthardt, R. 2004. Multidisciplinary investigations of alpine ice patches in southwest Yukon, Canada: Paleoenvironmental and paleobiological investigations. Arctic 57(3):247-259.

http://dx.doi.org/10.14430/arctic502

Feurdean, A., Bhagwat, S.A., Willis, K.J., Birks, H.J.B., Lischke, H., and Hickler, T. 2013. Tree migration-rates: Narrowing the gap between inferred post-glacial rates and projected rates. PloS One. http://dx.doi.org/10.1371/journal.pone.0071797

Gavelin, A. 1910. Über die Gletscher des Norra Storfjället und des Ammarfjället [On the glaciers of Norra Storfjället and Ammearfjället]. Stockholm: Sveriges Geologiska Undersökning Ca 5(IV). 42 p.

Holmlund, P., Karlén, W., and Grudd, H. 1996. Fifty years of mass balance and glacier front observations at the Tarfala Research Station. Geografiska Annaler 78A:105-114. http://dx.doi.org/10.2307/520972

Holtmeier, F.-K., and Broll, G. 2005. Sensitivity and response of Northern Hemisphere altitudinal and polar treelines to environmental change at landscape and local scales. Global Ecology and Biogeography 14(5):395 - 410. http://dx.doi.org/10.1111/j.1466-822X.2005.00168.x

Hormes, A., Müller, B.U., and Schlüchter, C. 2001. The Alps with little ice: Evidence for eight Holocene phases of reduced glacier extent in the Central Swiss Alps. The Holocene 11(3):255-265. http://dx.doi.org/10.1191/095968301675275728

Hormes, A., Karlén, W., and Possnert, G. 2004. Radiocarbon dating of palaeosol components in moraines in Lapland, northern Sweden. Quaternary Science Reviews 23(1819):2031-2043. http://dx.doi.org/10.1016/j.quascirev.2004.02.004

Humlum, O., Solheim, J.-E., and Stordahl, K. 2011. Identifying natural contributions to late Holocene climate change. Global and Planetary Change 79(1-2):145-156.

http://dx.doi.org/10.1016/j.gloplacha.2011.09.005

Ives, J.D. 1991. Landscape change and human response during a thousand years of climate fluctuations and volcanism: Skaftafell, southeast Iceland. Pirineos 137:5 - 50. http://dx.doi.org/10.3989/pirineos.1991.v137.193

Jansson, P., Richardson, C., and Jonsson, S. 1999. Assessment of requirements for cirque formation in northern Sweden. Annals of Glaciology 28(1):16-22.

http://dx.doi.org/10.3189/172756499781821959

Joerin, U.E., Nicolussi, K., Fischer, A., Stocker, T.F., and Schlüchter, C. 2008. Holocene optimum events inferred from subglacial sediments at Tschierva Glacier, eastern Swiss Alps. Quaternary Science Reviews 27(3-4):337-350. http://dx.doi.org/10.1016/j.quascirev.2007.10.016

Karlén, W. 1973. Holocene glacier and climatic variations, Kebnekaise Mountains, Swedish Lapland. Geografiska Annaler 55A:29-63. http://dx.doi.org/10.2307/520485

- 1976. Lacustrine sediments and tree-limit variations as indicators of Holocene climatic fluctuations in Lappland, northern Sweden. Geografiska Annaler 58A:1 - 34.

http://dx.doi.org/10.2307/520740
Karlén, W., and Kuylenstierna, J. 1996. On solar forcing of Holocene climate: Evidence from Scandinavia. The Holocene 6(3):359-365. http://dx.doi.org/10.1177/095968369600600311

Kirdyanov, A.V., Hagedorn, F., Knorre, A.A., Fedotova, E.V., Vaganov, E.A., Naurzbaev, M.M., Moiseev, P.A., and Rigling, A. 2012. 20th century tree-line advance and vegetation changes along an altitudinal transect in the Putorana Mountains, northern Siberia. Boreas 41(1):56-67.

http://dx.doi.org/10.1111/j.1502-3885.2011.00214.x

Koch, J., Clague, J.J., and Osborn, G.D. 2007. Glacier fluctuations during the past millennium in Garibaldi Provincial Park, southern Coast Mountains, British Columbia. Canadian Journal of Earth Sciences 44(9):1215-1233. http://dx.doi.org/10.1139/E07-019

Koehler, L., and Smith, D.J. 2011. Late Holocene glacial activity in Manatee Valley, southern Coast Mountains, British Columbia, Canada. Canadian Journal of Earth Sciences 48(3):603-618. http://dx.doi.org/10.1139/E10-087

Körner, C., and Paulsen, J. 2004. A world-wide study of high altitude treeline temperatures. Journal of Biogeography 31(5):713-732. http://dx.doi.org/10.1111/j.1365-2699.2003.01043.x

Kullman, L. 1984. Germinability of mountain birch (Betula pubescens ssp. tortuosa) along two altitudinal transects downslope from the tree-limit in Sweden. Reports from the Kevo Subarctic Research Station 19:11-18.

1995. Holocene tree-limit and climate history from the Scandes Mountains, Sweden. Ecology 76(8):2490-2502. http://dx.doi.org/10.2307/2265823

- 1999. Early Holocene tree growth at a high elevation site in the northernmost Scandes of Sweden (Lapland): A palaeobiogeographical case study based on megafossil evidence. Geografiska Annaler 81A:63-74.

http://dx.doi.org/10.1111/j.0435-3676.1999.00049.x

- 2002. Boreal tree taxa in the central Scandes during the Late-Glacial: Implications for Late-Quaternary forest history. Journal of Biogeography 29(9):1117-1124. http://dx.doi.org/10.1046/j.1365-2699.2002.00743.x

. 2004a. Early Holocene appearance of mountain birch (Betula pubescens ssp. tortuosa) at unprecedented high elevations in the Swedish Scandes: Megafossil evidence exposed by recent snow and ice recession. Arctic, Antarctic, and Alpine Research 36(2):172-180. http://dx.doi.org/10.1657/1523-0430(2004)036[0172:EHAOMB ]2.0.CO;2

. 2004b. A face of global warming - "ice birches" and a changing alpine plant cover. Geo-Öko 25:181-202.

- 2008. Early postglacial appearance of tree species in northern Scandinavia: Review and perspective. Quaternary Science Reviews 27(27-28):2467-2472.

http://dx.doi.org/10.1016/j.quascirev.2008.09.004

. 2010. A richer, greener and smaller alpine world: Review and projection of warming-induced plant cover change in the Swedish Scandes. Ambio 39(2):159-169.

http://dx.doi.org/10.1007/s13280-010-0021-8 
2013. Ecological tree line history and paleoclimate review of megafossil evidence from the Swedish Scandes. Boreas 42(3):555-567.

http://dx.doi.org/10.1111/bor.12003

Kullman, L., and Kjällgren, L. 2006. Holocene pine tree-line evolution in the Swedish Scandes: Recent tree-line rise and climate change in a long-term perspective. Boreas 35(1):159- 168 .

http://dx.doi.org/10.1111/j.1502-3885.2006.tb01119.x

Kullman, L., and Öberg, L. 2012. Melting glaciers and ice patches in Swedish Lapland provide new insights into the Holocene arboreal history. Geo-Öko 33:121-146.

Laaksonen, K. 1976. The dependence of mean air temperatures upon latitude and altitude in Fennoscandia (1921-1950). Annales Academiae Scientiarum Fennicae A3 119:1 - 19.

Lindgren, F., and Strömgren, M. 2001. Glaciärer berättar om forna tiders klimat [Glaciers tell of ancient climate]. Geologiskt Forum 8:8-11.

Ljungqvist, F.C. 2009. Temperature proxy records covering the last two millennia: A tabular and visual overview. Geografiska Annaler 91A:11-29. http://dx.doi.org/10.1111/j.1468-0459.2009.00350.x

Luetscher, M., Borreguero, M., Moseley, G.E., Spötl, C., and Edwards, R.L. 2013. Alpine permafrost thawing during the Medieval Warm Period identified from cryogenic cave carbonates. Cryosphere 7:1073-1081.

http://dx.doi.org/10.5194/tc-7-1073-2013

Luoto, T.P., Kaukolehto, M., Weckström, J., Korhola, A., and Väliranta, M. 2014. New evidence of warm early-Holocene summers in subarctic Finland based on an enhanced regional chironomid-based temperature calibration model. Quaternary Research 81(1):50-62.

http://dx.doi.org/10.1016/j.yqres.2013.09.010

Mahaney, W.C., and Kalm, V. 2012. Topographic and bioclimatic controls on soil/paleosol morphogenesis in the Norra Storfjället Mountains, Sweden. Geomorphology 173-174:43-51. http://dx.doi.org/10.1016/j.geomorph.2012.05.025

Menounos, B., Osborn, G., Clague, J.J., and Luckman, B.H. 2009. Latest Pleistocene and Holocene glacier fluctuations in western Canada. Quaternary Science Reviews 28(1-2):2049-2074.

http://dx.doi.org/10.1016/j.quascirev.2008.10.018

Möller, J.J. 1987. Shoreline relation and prehistoric settlement in northern Norway. Norsk Geografisk Tidsskrift 41(1):45-60. http://dx.doi.org/10.1080/00291958708552171

Mossberg, B., and Stenberg, L. 2003. Den nya nordiska floran [The new Nordic flora]. Stockholm: Wahlström and Widstrand.

Nesje, A. 2009. Latest Pleistocene and Holocene alpine glacier fluctuations in Scandinavia. Quaternary Science Reviews 28(21-22):2119-2136.

http://dx.doi.org/10.1016/j.quascirev.2008.12.016

Nesje, A., and Dahl, S.O. 2001. The Greenland 8200 cal yr BP event detected in loss-on-ignition profiles in Norwegian lacustrine sediment sequences. Journal of Quaternary Science 16(2):155- 166 .

http://dx.doi.org/10.1002/jqs.567
Nesje, A., Kvamme, M., Rye, N., and Løvlie, R. 1991. Holocene glacial and climate history of the Jostedalsbreen region, western Norway; evidence from lake sediments and terrestrial deposits. Quaternary Science Reviews 10(1):87-114.

http://dx.doi.org/10.1016/0277-3791(91)90032-P

Nesje, A., Bakke, J., Dahl, S.O., Lie, Ø., and Matthews, J.A. 2008. Norwegian mountain glaciers in the past, present and future. Global and Planetary Change 60(1-2):10-27. http://dx.doi.org/10.1016/j.gloplacha.2006.08.004

Nesje, A., Pilø, L.H., Finstad, E., Solli, B., Wangen, V., Ødegård, R.S., Isaksen, K., Støren, E.N., Bakke, D.I., and Andreassen, L.M. 2011. The climatic significance of artefacts related to prehistoric reindeer hunting exposed at melting ice patches in southern Norway. The Holocene 22(4):485-496.

http://dx.doi.org/10.1177/0959683611425552

Nicolussi, K., and Patzelt, G. 2000. Discovery of early Holocene wood and peat on the forefield of the Pasterze Glacier, Eastern Alps, Austria. The Holocene 10(2):191 - 199. http://dx.doi.org/10.1191/095968300666855842

Nicolussi, K., and Schlüchter, C. 2012. The 8.2 ka event-Calendardated glacier response in the Alps. Geology 40(9):819-822. http://dx.doi.org/10.1130/G32406.1

Öberg, L., and Kullman, L. 2011a. Recent glacier recession - a new source of postglacial treeline and climate history in the Swedish Scandes. Landscape Online 26:1-38.

2011b. Ancient subalpine clonal spruces (Picea abies): Sources of postglacial vegetation history in the Swedish Scandes. Arctic 64(2):183-196. http://dx.doi.org/10.14430/arctic4098

Påsse, T., and Andersson, L. 2005. Shore-level displacement in Fennoscandia calculated from empirical data. Geologiska Föreningen i Stockholms Förhandlingar 127(4):253-268. http://dx.doi.org/10.1080/11035890501274253

Paus, A. 2010. Vegetation and environment of Rødalen alpine area, central Norway, with emphasis on the early Holocene. Vegetation History and Archaeobotany 19(1):29-51. http://dx.doi.org/10.1007/s00334-009-0228-4

-2013. Human impact, soil erosion, and vegetation response lags to climate change: Challenges for the mid-Scandinavian pollen-based transfer-function temperature reconstructions. Vegetation History and Archaeobotany 22(3):269-284.

http://dx.doi.org/10.1007/s00334-012-0360-4

Paus, A., Velle, G., and Berge, J. 2011. The Lateglacial and early Holocene vegetation and environment in the Dovre mountains, central Norway, as signaled in two Lateglacial nunatak lakes. Quaternary Science Reviews 30(13-14):1780-1796.

http://dx.doi.org/10.1016/j.quascirev.2011.04.010

Reimer, P.J., Baillie, M.G.L., Bard, E., Bayliss, A., Beck, J.W., Blackwell, P.G., Bronk Ramsey, C., et al. 2009. IntCal09 and Marine09 radiocarbon age calibration curves, $0-50,000$ years cal BP. Radiocarbon 51(4):1111-1150.

Rosqvist, G., and Østrem, G. 1989 The sensitivity of a small icecap to climatic fluctuations. Geografiska Annaler 71A:99-103. http://dx.doi.org/10.2307/521013 
Scapozza, C., Lambiel, C., Reynard, E., Fallot, J.-M., Antognini, M., and Schoeneich, P. 2010. Radiocarbon dating of fossil wood remains buried by the Piancabella Rock Glacier, Blenio Valley (Ticino, southern Swiss Alps): Implications for rock glacier, treeline and climate history. Permafrost and Periglacial Processes 21(1):90-96.

http://dx.doi.org/10.1002/ppp.673

Scherrer, D., and Körner, C. 2011. Topographically controlled thermal-habitat differentiation buffers alpine plant diversity against climate warming. Journal of Biogeography 38(2):406-416.

http://dx.doi.org/10.1111/j.1365-2699.2010.02407.x

Schlüchter, C., and Jörin, U. 2004. Holz und Torffunde als Klimaindikatoren: Alpen ohne Gletscher? [Finds of wood and peat: Alps without glaciers?]. Die Alpen (6):34-47.

Schytt, V. 1959. The glaciers of the Kebnekajse-Massif. Geografiska Annaler 41(4):213-227.

Seppä, H., and Birks, H.J.B. 2001. July mean temperature and annual precipitation trends during the Holocene in the Fennoscandian tree-line area: Pollen-based climate reconstructions. The Holocene 11(5):527-539.

http://dx.doi.org/10.1191/095968301680223486

Seppä, H., Hannon, G.E., and Bradshaw, R.H.W. 2004. Holocene history of alpine vegetation and forestline on Pyhäkero Mountain, northern Finland. Arctic, Antarctic, and Alpine Research 36(4):607-614.

http://dx.doi.org/10.1657/1523-0430(2004)036[0607:HHOAVA ]2.0.CO;2
Shemesh, A., Rosqvist, G., Rietti-Shati, M., Rubensdotter, L., Bigler, C., Yam, R., and Karlén, W. 2001. Holocene climatic change in Swedish Lapland inferred from an oxygenisotope record of lacustrine biogenic silica. The Holocene 11(4):447-454.

http://dx.doi.org/10.1191/095968301678302887

Snowball, I., and Sandgren, P. 1996. Lake sediment studies of Holocene glacial activity in the Kårsa valley, northern Sweden: Contrasts in interpretation. The Holocene 6(3):367-372. http://dx.doi.org/10.1177/095968369600600312

Svenonius, F.V. 1910. Studien über den Kårso- und die Kebnegletscher nebst Notizen über andere Gletscher in Jukkasjärvigebirge [Studies on the Kårso- and Kebne glaciers with notes on other glaciers in Jukkasjärvigebirge]. Sveriges Geologiska Undersökning Ca 5:1-54.

Svensson, N.-O. 1991. Late Weichselian and early Holocene shore displacement in the central Baltic Sea. Quaternary International 9:7-26. http://dx.doi.org/10.1016/1040-6182(91)90059-W

Tinner, W., and Kaltenrieder, P. 2005. Rapid responses of highmountain vegetation to early Holocene environmental changes in the Swiss Alps. Journal of Ecology 93(5):936-947.

http://dx.doi.org/10.1111/j.1365-2745.2005.01023.x

Wiles, G.C., Barclay, D.J., Calkin, P.E., and Lowell, T.V. 2008. Century to millennial-scale temperature variations of the last two thousand years indicated from glacial geologic records of southern Alaska. Global and Planetary Change 60(12): $115-125$.

http://dx.doi.org/10.1016/j.gloplacha.2006.07.036

APPENDIX 1. Radiocarbon dates of tree remains. Lab. codes marked with an asterisk $\left(^{*}\right)$ denote AMS dates. "Relative elevation" refers to the difference in altitude between the sampling site and the nearest tree line of the concerned species. Source: $1-$ Öberg and Kullman, 2011a; 2 - Kullman and Öberg, 2013; 3 - this study.

\begin{tabular}{|c|c|c|c|c|c|c|c|c|c|c|c|}
\hline Locality & ${ }^{\circ} \mathrm{N}$ lat. & ${ }^{\circ} \mathrm{E}$ long. & $\begin{array}{l}\text { Relative } \\
\text { elevation }\end{array}$ & $\begin{array}{l}\text { Altitude } \\
\text { (m a.s.1.) }\end{array}$ & Species & Lab. code & $\begin{array}{l}\text { Radio- } \\
\text { carbon } \\
\text { age }\end{array}$ & $\begin{array}{l}\text { Calibrated } \\
1 \delta \text { range } \\
\left({ }^{14} \mathrm{C} \text { yr BP }\right)\end{array}$ & $\begin{array}{l}\text { Intercept } \\
\text { (cal yr BP) }\end{array}$ & $\begin{array}{l}\text { Sample } \\
\text { size } \\
(\mathrm{cm})\end{array}$ & Source \\
\hline Tärnaglaciären & 6550945 & 1516728 & 270 & 1070 & Betula pubescens & Beta-284450 & $5430 \pm 60$ & $6290-6190$ & 6280 & $18 \times 7$ & 1 \\
\hline Tärnaglaciären & 6558916 & 1516681 & 270 & 1070 & Betula pubescens & Beta-284449 & $4850 \pm 50$ & $5610-5580$ & 5590 & $20 \times 8$ & 1 \\
\hline Tärnaglaciären & 6550945 & 1516661 & 270 & 1070 & Betula pubescens & Beta-284455 & $5240 \pm 50$ & $6100-5930$ & 5990 & $5 \times 4$ & 1 \\
\hline Tärnaglaciären & 6550910 & 1516734 & 265 & 1065 & Betula pubescens & Beta-268653 & $5880 \pm 60$ & $6750-6650$ & 6680 & $17 \times 7$ & 1 \\
\hline Tärnaglaciären & 6550913 & 1516724 & 260 & 1060 & Betula pubescens & Beta-268654 & $6220 \pm 60$ & $7240-7020$ & 7160 & $19 \times 8$ & 1 \\
\hline Tärnaglaciären & 6550875 & 1517653 & 225 & 1025 & Betula pubescens & Beta-264395 & $5990 \pm 70$ & $6920-6740$ & 6820 & $13 \times 6$ & 1 \\
\hline Tärnaglaciären & 6550927 & 1516654 & 275 & 1075 & Betula pubescens & Beta-284467 & $4020 \pm 50$ & $4530-4420$ & 4480 & $15 \times 7$ & 1 \\
\hline Tärnaglaciären & 6550896 & 1516761 & 270 & 1070 & Betula pubescens & Beta-284447 & $4950 \pm 50$ & $5730-5610$ & 5660 & $30 \times 11$ & 1 \\
\hline Tärnaglaciären & 6550824 & 1516843 & 285 & 1085 & Pinus sylvestris & Beta-284448 & $8110 \pm 40$ & $9030-9010$ & 9020 & $50 \times 12$ & 1 \\
\hline Tärnaglaciären & 6550937 & 1516648 & 270 & 1070 & Pinus sylvestris & Beta-284453 & $5110 \pm 50$ & $5920-5760$ & 5900 & $10 \times 3$ & 1 \\
\hline Tärnaglaciären & 6550950 & 1516700 & 260 & 1060 & Pinus sylvestris & Beta-284454 & $7330 \pm 60$ & $8190-8040$ & 8170 & $45 \times 14$ & 1 \\
\hline Tärnaglaciären & 6550947 & 1516834 & 270 & 1070 & Pinus sylvestris & Beta-264394 & $8520 \pm 70$ & $9540-9480$ & 9530 & $35 \times 10$ & 1 \\
\hline Tärnaglaciären & 6550913 & 1516724 & 265 & 1065 & Pinus sylvestris & Beta-268655 & $7600 \pm 60$ & $8420-8370$ & 8400 & $40 \times 11$ & 1 \\
\hline Tärnaglaciären & 6550942 & 1516650 & 270 & 1070 & Betula pubescens & Beta-362589 & $5440 \pm 40$ & $6290-6210$ & 6280 & $12 \times 7$ & 3 \\
\hline Tärnaglaciären & 6550913 & 1516658 & 265 & 1065 & Betula pubescens & Beta-362590 & $7710 \pm 40$ & $8540-8430$ & 8485 & $10 \times 5$ & 3 \\
\hline Tärnaglaciären & 6550936 & 1516672 & 265 & 1065 & Betula pubescens & Beta-362591 & $8160 \pm 40$ & $9130-9020$ & 9060 & $8 \times 4$ & 3 \\
\hline Tärnaglaciären & 6550927 & 1516680 & 265 & 1065 & Betula pubescens & Beta-362592 & $8070 \pm 40$ & $9020-9000$ & 9010 & $22 \times 5$ & 3 \\
\hline Tärnaglaciären & 6550910 & 1516677 & 270 & 1070 & Pinus sylvestris & Beta-362585 & $8170 \pm 40$ & $9130-9030$ & 9090 & $42 \times 11$ & 3 \\
\hline Tärnaglaciären & 6550951 & 1516654 & 265 & 1065 & Pinus sylvestris & Beta-358468 & $4370 \pm 30$ & $4970-4870$ & 4915 & $43 \times 6$ & 3 \\
\hline Tärnaglaciären & 6550918 & 1516659 & 265 & 1065 & Pinus sylvestris & Beta-362587 & $5260 \pm 40$ & $6170-5940$ & 5990 & $20 \times 5$ & 3 \\
\hline Tärnaglaciären & 6550923 & 1516656 & 265 & 1065 & Pinus sylvestris & Beta-362588 & $6190 \pm 30$ & $7160-7020$ & 7160 & $12 \times 8$ & 3 \\
\hline Östra Syterglaciären & 6553748 & 1516984 & 390 & 1190 & Betula pubescens & Beta-284469 & $8080 \pm 70$ & $9030-8990$ & 9010 & $29 \times 6$ & 1 \\
\hline Murtserglaciären & 6550654 & 1514291 & 555 & 1355 & Betula pubescens & Beta-332297 & $7980 \pm 40$ & $8990-8770$ & 8885 & $35 \times 8$ & 2 \\
\hline Murtserglaciären & 6550779 & 1514605 & 625 & 1425 & Betula pubescens & Beta-332288 & $8230 \pm 40$ & $9280-9130$ & 9195 & $30 \times 8$ & 2 \\
\hline Murtserglaciären & 6550727 & 1515561 & 500 & 1300 & Betula pubescens & Beta-332283 & $7660 \pm 40$ & $8450-8410$ & 8420 & $11 \times 5$ & 2 \\
\hline Murtserglaciären & 6550576 & 1514882 & 520 & 1210 & Pinus sylvestris & Beta-332287 & $8220 \pm 40$ & $9270-9120$ & 9190 & $40 \times 10$ & 2 \\
\hline
\end{tabular}




\begin{tabular}{|c|c|c|c|c|c|c|c|c|c|c|c|}
\hline Locality & ${ }^{\circ} \mathrm{N}$ lat. & ${ }^{\circ} \mathrm{E}$ long. & $\begin{array}{c}\text { Relative } \\
\text { elevation }\end{array}$ & $\begin{array}{l}\text { Altitude } \\
\text { (m a.s.l.) }\end{array}$ & Species & Lab. code & $\begin{array}{l}\text { Radio- } \\
\text { carbon } \\
\text { age }\end{array}$ & $\begin{array}{l}\text { Calibrated } \\
1 \delta \text { range } \\
\left({ }^{14} \mathrm{C} \text { yr BP }\right)\end{array}$ & $\begin{array}{l}\text { Intercept } \\
\text { (cal yr BP) }\end{array}$ & $\begin{array}{l}\text { Sample } \\
\text { size } \\
(\mathrm{cm}) \quad \mathrm{S}\end{array}$ & Source \\
\hline Murtserglaciären & 6550527 & 1514787 & 515 & 1205 & Pinus sylvestris & Beta-332286 & $7910 \pm 40$ & $8770-8630$ & 8675 & $13 \times 5$ & 2 \\
\hline Murtsernjuone & 6550546 & 1513613 & 350 & 1150 & Betula pubescens & Beta-332290 & $7200 \pm 40$ & $8020-7970$ & 8010 & $20 \times 5$ & 2 \\
\hline Murtsernjuone & 6550387 & 1513589 & 285 & 1085 & Betula pubescens & Beta-322281 & $4640 \pm 30$ & $5450-5320$ & 5380 & $12 \times 5$ & 2 \\
\hline Murtsernjuone & 6550563 & 1513588 & 470 & 1160 & Pinus sylvestris & Beta- 332280 & $7140 \pm 40$ & $8000-7940$ & 7960 & $18 \times 7$ & 2 \\
\hline Murtsergure & 6549623 & 1516427 & 355 & 1155 & Betula pubescens & Beta-332298 & $5300 \pm 40$ & $6180-6990$ & 6095 & $30 \times 7$ & 2 \\
\hline Murtsergure & 6549626 & 1516493 & 350 & 1150 & Betula pubescens & Beta-332295 & $7770 \pm 40$ & $8590-8520$ & 8550 & $40 \times 8$ & 2 \\
\hline Murtsergure & 6549606 & 1516568 & 330 & 1130 & Betula pubescens & Beta-332294 & $7740 \pm 40$ & $8580-8570$ & 8540 & $15 \times 13$ & 2 \\
\hline Murtsergure & 6549675 & 1516180 & 375 & 1175 & Betula pubescens & Beta-332292 & $6130 \pm 40$ & $7150-6950$ & 7000 & $50 \times 9$ & 2 \\
\hline Murtsergure & 6549590 & 1516568 & 330 & 1130 & Betula pubescens & Beta-332285 & $7340 \pm 30$ & $8180-8160$ & 8170 & $30 \times 6$ & 2 \\
\hline Murtsergure & 6549622 & 1516430 & 460 & 1150 & Pinus sylvestris & Beta-332296 & $8110 \pm 40$ & $9070-9010$ & 9020 & $50 \times 8$ & 2 \\
\hline Murtsergure & 6549605 & 1516672 & 425 & 1115 & Pinus sylvestris & Beta-332293 & $5980 \pm 30$ & $6860-6760$ & 6800 & $45 \times 8$ & 2 \\
\hline Murtsergure & 6549590 & 1516400 & 460 & 1150 & Pinus sylvestris & Beta- 332282 & $7670 \pm 40$ & $8510-8410$ & 8430 & $40 \times 8$ & 2 \\
\hline Kårsajökeln & 6821610 & 1821096 & 80 & 930 & Betula pubescens & Beta- 250909 & $6130 \pm 60$ & $7160-6940$ & 7000 & $40 \times 7$ & 1 \\
\hline Kårsajökeln & 6821726 & 1820156 & 130 & 980 & Betula pubescens & Beta-250917 & $7920 \pm 50$ & $8960-8630$ & 8710 & $60 \times 9$ & 1 \\
\hline Kårsajökeln & 6821744 & 1819853 & 140 & 990 & Betula pubescens & Beta-264383 & $8160 \pm 90$ & $9260-9010$ & 9060 & $30 \times 12$ & 1 \\
\hline Kårsajökeln & 6821731 & 1820152 & 135 & 985 & Betula pubescens & Beta-264385 & $7250 \pm 60$ & $8160-8000$ & 8030 & $18 \times 7$ & 1 \\
\hline Kårsajökeln & 6821628 & 1820292 & 165 & 965 & Betula pubescens & Beta-264386 & $8290 \pm 70$ & $9420-9140$ & 9290 & $20 \times 8$ & 1 \\
\hline Kårsajökeln & 6821744 & 1819885 & 155 & 955 & Pinus sylvestris & Beta-250906 & $10130 \pm 60$ & $11980-11680$ & $0 \quad 11760$ & $30 \times 8$ & 1 \\
\hline Kårsajökeln & 6821771 & 1819969 & 140 & 940 & Pinus sylvestris & Beta-250914 & $8270 \pm 60$ & $9400-9130$ & 9280 & $30 \times 12$ & 1 \\
\hline Kårsajökeln & 6821735 & 1819882 & 190 & 990 & Pinus sylvestris & Beta-264384 & $5980 \pm 50$ & $6890-6740$ & 6790 & $40 \times 15$ & 1 \\
\hline Kårsajökeln & 6821629 & 1820316 & 150 & 950 & Pinus sylvestris & Beta-264387 & $6130 \pm 60$ & $7160-6940$ & 7000 & $7 \times 4$ & 1 \\
\hline Kårsajökeln & 6821657 & 1820531 & 145 & 945 & Pinus sylvestris & Beta-264388 & $8250 \pm 60$ & $9380-9120$ & 9260 & $15 \times 5$ & 1 \\
\hline Kårsajökeln & 6821728 & 1819883 & 140 & 990 & Betula pubescens & Beta-362594 & $2020 \pm 30$ & $1990-1900$ & 1950 & $15 \times 6$ & 3 \\
\hline Kårsajökeln & 6821794 & 1819797 & 150 & 1000 & Betula pubescens & Beta-362596 & $7000 \pm 40$ & $7940-7730$ & 7840 & $8 \times 4$ & 3 \\
\hline Kårsajökeln & 6821680 & 1820065 & 445 & 965 & Pinus sylvestris & Beta-362593 & $8240 \pm 40$ & $9250-9150$ & 9200 & $9 \times 4$ & 3 \\
\hline Kårsajökeln & 6821714 & 1819868 & 470 & 990 & Pinus sylvestris & Beta-362595 & $7800 \pm 40$ & $8600-8550$ & 8590 & $11 \times 7$ & 3 \\
\hline Slåttatjåkka & 6821886 & 1841110 & 175 & 1025 & Betula pubescens & Beta-284457 & $4760 \pm 50$ & $5590-5460$ & 5530 & $45 \times 7$ & 1 \\
\hline Slåttatjåkka & 6821930 & 1841297 & 165 & 1015 & Betula pubescens & Beta-284458 & $6900 \pm 60$ & $7790-7670$ & 7700 & $13 \times 6$ & 1 \\
\hline Slåttatjåkka & 6821891 & 1841131 & 180 & 1030 & Betula pubescens & Beta-264392 & $8210 \pm 70$ & $9290-9030$ & 9130 & $30 \times 8$ & 1 \\
\hline Slåttatjåkka & 6821888 & 1841128 & 180 & 1030 & Betula pubescens & Beta-264391 & $8510 \pm 70$ & $9540-9480$ & 9520 & $31 \times 5$ & 1 \\
\hline Slåttatjåkka & 6821887 & 1841126 & 180 & 1030 & Pinus sylvestris & Beta- 264390 & $8380 \pm 80$ & $9480-9300$ & 9440 & $14 \times 7$ & 1 \\
\hline Slåttatjåkka & 6821861 & 1841293 & 155 & 1005 & Pinus sylvestris & Beta-284456 & $7690 \pm 50$ & $8540-8420$ & 8450 & $53 \times 10$ & 1 \\
\hline Slåttatjåkka & 6821474 & 1841305 & 240 & 1090 & Pinus sylvestris & Beta-284461 & $7710 \pm 70$ & $8570-8420$ & 8490 & $40 \times 10$ & 1 \\
\hline Kärkerieppe & 6823189 & 1818025 & 370 & 1050 & Betula pubescens & Beta-284459 & $6090 \pm 60$ & $7140-6890$ & 6950 & $18 \times 7$ & 1 \\
\hline Kärkerieppe & 6823099 & 1817956 & 380 & 1060 & Betula pubescens & Beta-284460 & $4600 \pm 50$ & $5440-5300$ & 5310 & $17 \times 6$ & 1 \\
\hline Kåppasglaciären & 6821807 & 1834763 & 155 & 1025 & Betula pubescens & Beta-284462 & $6100 \pm 60$ & $7150-6900$ & 6980 & $50 \times 12$ & 1 \\
\hline Kåppasglaciären & 6821833 & 1834819 & 145 & 1015 & Betula pubescens & Beta-284463 & $3900 \pm 60$ & $4420-4240$ & 4400 & $12 \times 5$ & 1 \\
\hline Kåppasglaciären & 6821841 & 1834883 & 145 & 1015 & Betula pubescens & Beta-284465 & $4270 \pm 50$ & $4860-4830$ & 4840 & $13 \times 6$ & 1 \\
\hline Kåppasglaciären & 6821808 & 1824764 & 160 & 1030 & Pinus sylvestris & Beta-284464 & $6870 \pm 60$ & $7750-7660$ & 7680 & $30 \times 10$ & 1 \\
\hline Låktatjåkka & 6824603 & 1832415 & 295 & 975 & Betula pubescens & Beta-284472 & $5040 \pm 60$ & $5900-5710$ & 5800 & $18 \times 8$ & 1 \\
\hline Låktatjåkka & 6824590 & 1832372 & 300 & 980 & Pinus sylvestris & Beta-284471 & $8020 \pm 70$ & $9010-8770$ & 8990 & $36 \times 10$ & 1 \\
\hline Kittelglaciären & 6752996 & 1831010 & 320 & 1230 & Betula pubescens & Beta-358470 & $6760 \pm 30$ & $7620-7580$ & 7610 & $30 \times 9$ & 3 \\
\hline Kittelglaciären & 6753058 & 1830952 & 330 & 1240 & Betula pubescens & Beta-358475 & $8470 \pm 40$ & $9520-9470$ & 9490 & $14 \times 7$ & 3 \\
\hline Kittelglaciären & 6752971 & 1831002 & 300 & 1210 & Betula pubescens & Beta-358477 & $7310 \pm 40$ & $8180-8040$ & 8160 & $13 \times 8$ & 3 \\
\hline Kittelglaciären & 6752885 & 1831099 & 285 & 1195 & Betula pubescens & Beta-358478 & $7690 \pm 40$ & $8540-8420$ & 8450 & $10 \times 7$ & 3 \\
\hline Kittelglaciären & 6752885 & 1831099 & 285 & 1195 & Betula pubescens & Beta358684 & $7830 \pm 40$ & $8630-8590$ & 8600 & $18 \times 9$ & 3 \\
\hline Kittelglaciären & 6752885 & 1831099 & 285 & 1195 & Betula pubescens & Beta-358479 & $7920 \pm 40$ & $8930-8640$ & 8720 & $21 \times 7$ & 3 \\
\hline Kittelglaciären & 6753063 & 1830944 & 295 & 1205 & Betula pubescens & Beta-362592 & $8070 \pm 40$ & $9020-9000$ & 9010 & $16 \times 6$ & 3 \\
\hline Kittelglaciären & 6753038 & 1831019 & 330 & 1240 & Betula pubescens & Beta-358472 & $6040 \pm 30$ & $6940-6810$ & 6890 & $14 \times 8$ & 3 \\
\hline Kittelglaciären & 6753065 & 1830974 & 330 & 1240 & Betula pubescens & Beta- 358473 & $5880 \pm 30$ & $6740-6670$ & 6695 & $19 \times 7$ & 3 \\
\hline Kittelglaciären & 6753066 & 1830945 & 655 & 1205 & Pinus sylvestris & Beta-358469 & $8050 \pm 40$ & $9010-8990$ & 9000 & $23 \times 8$ & 3 \\
\hline Kittelglaciären & 6753002 & 1831012 & 680 & 1230 & Pinus sylvestris & Beta-358471 & $7800 \pm 40$ & $8600-8550$ & 8590 & $18 \times 8$ & 3 \\
\hline Kittelglaciären & 6753066 & 1830945 & 655 & 1205 & Pinus sylvestris & Beta-358469 & $8050 \pm 40$ & $9010-8990$ & 9000 & $12 \times 5$ & 3 \\
\hline Kittelglaciären & 6753046 & 1831268 & 690 & 1240 & Pinus sylvestris & Beta-358474 & $8080 \pm 40$ & $9020-9000$ & 9010 & $13 \times 5$ & 3 \\
\hline Storglaciären & 6754189 & 1836540 & 205 & 1115 & Betula pubescens & Beta-358480 & $5650 \pm 30$ & $6430-6410$ & 6420 & $15 \times 7$ & 3 \\
\hline Storglaciären & 6754285 & 1836708 & 190 & 1100 & Betula pubescens & Beta-358690 & $7720 \pm 40$ & $8550-8430$ & 8490 & $14 \times 6$ & 3 \\
\hline Storglaciären & 6754205 & 1836701 & 195 & 1105 & Betula pubescens & Beta-358483 & $6110 \pm 30$ & $7000-6940$ & 6980 & $19 \times 8$ & 3 \\
\hline Murtserglaciären & 6550585 & 1514774 & 515 & 1225 & Picea abies & Beta-332275* & $7360 \pm 40$ & $8190-8170$ & 8180 & Cone & 2 \\
\hline Murtsernjuone & 6550563 & 1513588 & 515 & 1160 & Picea abies & Beta-332274* & $7690 \pm 40$ & $8540-8420$ & 8450 & Cone & 2 \\
\hline Storglaciären & 6754287 & 183670 & 555 & 1105 & Picea abies & Beta-366360* & $7650 \pm 40$ & $8420-8340$ & 8380 & Cone shell & 113 \\
\hline Murtsergure & 6549599 & 1516574 & 510 & 1125 & Larix sibirica & Beta-332277* & $6410 \pm 30$ & $7420-7310$ & 7320 & Cone & 2 \\
\hline Murtsergure & 6549599 & 1516574 & 1125 & 395 & Alnus incana & Beta-332278* & $7280 \pm 40$ & $8170-8020$ & 8000 & Leaf & 2 \\
\hline Murtsergure & 6549625 & 1516669 & 1115 & 465 & Populus tremula & Beta $332276^{*}$ & $7790 \pm 40$ & $8600-8540$ & 8590 & Leaf & 2 \\
\hline Murtsergure & 6549599 & 1516574 & 1125 & 345 & Sorbus aucuparia & Beta-332279* & $7890 \pm 40$ & $8750-8600$ & 8640 & Leaf & 2 \\
\hline Tärnaglaciären & 6550927 & 1516654 & 1075 & & Peat & Beta-268652* & $3590 \pm 50$ & $3970-3840$ & 3890 & $13 \times 11$ & 1 \\
\hline Murtsergure & 6549565 & 1516591 & 1115 & & Peat & Beta-322289* & $4500 \pm 40$ & $5300-5050$ & 5175 & $15 \times 15$ & 2 \\
\hline Kittelglaciären & 6757899 & 1830978 & 1230 & & Peat & Beta-366365* & $4650 \pm 30$ & $5340-5310$ & 5380 & $14 \times 14$ & 3 \\
\hline Storglaciären & 6754287 & 1836700 & 1105 & & Peat & Beta-366360* & $7650 \pm 40$ & $8420-8340$ & 8380 & $17 \times 12$ & 3 \\
\hline Kårsajökeln & 6821644 & 1820126 & 982 & & Peat & Beta-366362* & $6980 \pm 40$ & $7880-7700$ & 7830 & $12 \times 10$ & 3 \\
\hline
\end{tabular}

